Original Research Paper

\title{
Pelatihan Pengembangan Model Penilaian Otentik (Authentic Assessment) pada Pembelajaran Bahasa Inggris Sekolah Dasar bagi Guru-Guru Bahasa Inggris Sekolah Dasar Di Kabupaten Lombok Barat
}

\author{
Nurachman Hanafi ${ }^{1}$, Santi Farmasari ${ }^{2 *}$, Mahyuni $^{3}$, Muhammad Amin ${ }^{4}$, Yuni Budi Lestari ${ }^{5}$ \\ ${ }^{1}$ English Education Program, University of Mataram, Mataram, Indonesia \\ ${ }^{2}$ English Education Program, University of Mataram, Mataram, Indonesia \\ ${ }^{3}$ English Education Program, University of Mataram, Mataram, Indonesia \\ ${ }^{4}$ English Education Program, University of Mataram, Mataram, Indonesia. \\ ${ }^{5}$ English Education Program, University of Mataram, Mataram, Indonesia.
}

DOI: https://doi.org/10.29303/jpmpi.v4i2.855

Sitasi: Hanafi. N., Farmasari, S., Mahyuni., Amin, M., \& Lestari, Y. B. (2021). Pelatihan Pengembangan Model Penilaian Otentik (Authentic Assessment) pada Pembelajaran Bahasa Inggris Sekolah Dasar bagi Guru-Guru Bahasa Inggris Sekolah Dasar Di Kabupaten Lombok Barat. Jurnal Pengabdian Magister Pendidikan IPA, 4(2)

\section{Article history \\ Received: 30 April 2021 \\ Revised: 23 Mei 2021 \\ Accepted: 30 Juni 2021 \\ *Corresponding Author: \\ Santi Farmasari \\ English Education Program, \\ University of Mataram, \\ Mataram, Indonesia. \\ Email: \\ santifarmasari@unram.ac.id}

\begin{abstract}
Secara umum, program Pengabdian Kepada Masyarakat ini dilaksanakan dengan tujuan Menyampaikan materi tentang rubrik penilaian pembelajaran bahasa Inggris dan secara khusus tentang bentuk-bentuk penilaian otentik yang dapat diterapkan pada pembelajaran Bahasa Inggris di sekolah dasar. Kegiatan pengabdian ini dilaksanakan dengan melibatkan guru-guru bahasa Inggris Sekolah Dasar di Kabupaten Lombok Barat. Pealtihan dilaksanakan dalam tiga tahap, yaitu (1) penyampaian materi tentang penilaian pembelajaran bahasa dan penilaian otentik, (2) diskusi dan kerja kelompok mengembangkan rencana atau prosedur penilaian berdasarkan kompetensi dasar atau indikator yang telah ditetapkan, dan (3) presentasi hasil pengembangan dan revisi bersama rencana penilaian yang telah dikembangkan. Luaran dari kegiatan pengabdian ini adalah (1) pemahaman guru tentang penilaian pembelajaran bahasa Inggris, (2) pemahaman guru tentang penilaian otentik dan (3) keterampilan pengembangan penilaian otentik, prosedur dan instrumen penilaian.
\end{abstract}

Keywords: Penilaian Otentik, Pembelajaran Bahasa Inggris Sekolah Dasar

\section{Pendahuluan}

Penilaian atau evaluasi adalah suatu proses pengumpulan, pengolahan, dan pemaknaan data (informasi) untuk menentukan kualitas sesuatu yang terkandung dalam data tersebut (Koufman dan Thomas, 1980; Batzle, 1992; Toutman, 1994 di Musaddat, dkk., 2011). Dalam pembelajaran bahasa, tidak hanya bahasa asing, data yang dimaksud adalah data rekaman progress siswa selama pembelajaran dan pada akhir pembelajaran yang dapat diperoleh melalui berbagai cara atau teknik penilaian atau evaluasi baik itu melalui penilaian yang sifatnya formatif maupun sumatif. Penilaian formatif, apabila dilaksanakan dengan efektif, dapat secara sifnifikan meningkatkan kompetensi atau kemampuan siswa dan kualitas guru serta kualitas pengajaran (Moss, C.M., \& Brookhart, S.M., 2009), sedangkan penilaian sumatif lebih bersifat penilaian rangkuman terhadap kemampuan siswa setelah semua materi 
pembelajaran tersampaikan. Namun, apapun jenis atau teknik penilaian yang dilakukan oleh guru, seyogyanya data yang diperoleh dari penilaian atau evaluasi pembelajaran haruslah dapat dikaji dan digunakan sebagai bahan refleksi terhadap apa yang sudah dan belum maksimal dilakukan di semua aspek pembelajaran dan pengajaran baik itu dari aspek siswa, metode atau pendekatan yang digunakan, maupun dari aspek pengajar atau guru.

Salah satu model penilaian yang banyak dibicarakan dewasa ini dan dianggap sebagai jalan keluar dari permasalahan-permasalahan penilaian yang terlalu mengedepankan penilaian di akhir periode pembelajaran adalah model penilaian otentik (authentic assessment). Menurut Callison (2009) penilaian otentik adalah penilaian proses yang di dalamnya melibatkan berbagai kineja yang mencerminkan bagaimana peserta didik belajar, capaian hasil, motivasi dan sikap yang terkait dengan aktivitas pembelajaran. Penilaian model ini mengedepankan kinerja siswa berupa unjuk kerja-unjuk kerja yang dapat ditampilkan peserta didik selama berlangsungnya kegiatan pembelajaran yang kesemuanya ini lebih luas daripada sekedar ujian tertulis jawaban singkat sebagaimana dalam tes tradisional.

Penilaian otentik dapat memfasilitasi pembelajar untuk menampilkan dan mendemonstrasikan kemampuan aktual mereka dengan berbagai cara dan dapat dilaksanakan kapan saja selama proses pembelajaran. Beberapa bentuk penilaian otentik yang dapat dilaksanakan pada pembelajaran bahasa Inggris adalah dengan memberikan tugas wawancara, pengamatan, angket, catatan lapangan/harian, portofolio, proyek dan lain-lain. Penilaian yang dilakukan melalui cara yang beragam yang meliputi proses dan produk inilah yang kemudian memberikan nilai otentik, nyata, konkret, hasil tampilan nyata, akurat dan bermakna (Nurgiyantoro, 2012:306). Penggunaan model penilaian otentik dipercaya dapat menggambarkan kemampuan pembelajar yang sesungguhnya sehingga penilaian yang kita laksanakan bisa dikategorikan penilaian yang valid (Hughes, 2003:26). Valid dalam hal ini artinya bahwa penilaian yang kita laksanakan memang benar-benar mengukur keterampilan atau kemampuan yang harus dikuasai oleh pembelajar. Apabila yang ingin diukur adalah kemampuan berbicara (speaking) maka seyogyanyalah tes yang diberikan adalah tes berbicara bukan tes pilihan ganda, uraian, atau tes tulis lainnya. Sebaliknya, apabila kemampuan menulis paragrap naratif yang harus dikuasai pembelajar maka pengajar dalam hal ini wajib menilai kemampuan menulis pembelajar dengan memberikan tes menulis baik itu pada tingkatan kalimat, paragrap dan/atau cerita. Artinya bahwa di dalam jaminan kualitas penilaian yang dilakukan harus bisa melihat construct dari tes itu sendiri atau sering disebut Construct Validity, yaitu menjamin bahwa evaluasi pembelajaran yang dilakukan memang benarbenar mengukur hal-hal yang harus diukur atau dinilai bukan hal yang lainnya (Luoma, 2004:7).

Sudah menjadi permasalahan umum dan sulit terbantahkan bahwa kualitas penilaian keterampilan berbahasa khususnya bahasa Inggris masih sangat rendah. Kenyataan yang sering kita temui di lapangan adalah guru hanya terpaku pada cara menilai yang kaku, guru tidak menganggap dirinya sedang menilai apabila tidak memberikan soal dan siswa harus menulis jawaban mereka untuk kemudian diperiksa oleh guru, apapun keterampilan bahasa yang sedang mereka pelajari, dan penilaian dilakukan pada akhir periode pembelajaran. Singkatnya, penilaian yang selama ini dianggap paling benar adalah menilai produk siswa di akhir masa pembelajaran atau di akhir setiap kompetensi yang diajarkan (product assessment).

Mahyuni, dkk (2013) misalnya menemukan bahwa teknik dan bentuk penilaian yang paling dominan digunakan guru di jenjang Sekolah Dasar adalah bentuk tes objektif yaitu Pilihan Ganda (PG) yang 
digunakan untuk mengukur keseluruhan kompetensi bahasa pembelajar. Tidak ditemukannya teknik dan bentuk penilaian yang menekankan pada unjuk kerja nyata siswa merupakan salah satu contoh bahwa pengajar dalam hal ini lebih cenderung memilih teknik dan bentuk penilaian yang mudah dilaksanakan dan diolah hasilnya. Namun perlu disadari bahwa bahasa adalah suatu keterampilan yang dinamis dan konstekstual, bukan suatu keterampilan harga pasti, sehingga cara yang paling tepat untuk menilai perkembangan keterampilan berbahasa siswa adalah dengan memadukan penilaian pada proses dan hasil pembelajaran sehingga hasil penilaian yang diperoleh bisa memberikan gambaran menyeluruh tentang perkembangan pembelajaran serta hasil pembelajaran.

Permasalahan-permasalahan penilaian proses dan hasil pembelajaran Bahasa Inggris seperti yang dikemukakan diatas tidak hanya ditemukan pada satu tingkatan pendidikan saja, melainkan terjadi di semua jenjang mulai dari jenjang Sekolah Dasar sampai ke Perguruan Tinggi. Upaya-upaya perbaikan kearah peningkatan kualitas penilaian pembelajaran sebenarnya sudah sering dilakukan baik itu atas prakarsa individu guru, prakarsa sekolah, gugus, dan dinas pendidikan setempat dalam bentuk seminar-seminar, pelatihan, lokakarya, Lesson Study dan sebagainya. Namun fakta di lapangan membuktikan bahwa upaya-upaya tersebut belum sepenuhnya menyentuh semua jenjang pendidikan. Sekolah Menengah, SLTP dan SMU, biasanya paling banyak mendapat perhatian dengan diadakannya seminarseminar, pelatihan, lokakarya bagi guru-guru SLTP dan SMU, tetapi belum banyak atau bahkan bisa dikatakan hampir belum menyentuh level di bawahnya yaitu Sekolah Dasar. Walaupun seminar atau pelatihan tentang Bahasa Inggris Sekolah Dasar sering dilaksanakan namun belum ada yang membahas masalah penilaian secara lebih mendalam. Guru-guru Bahasa Inggris SD sangat jarang mendapatkan pelatihan atau pembinaan dalam hal yang satu ini. Sehingga model-model penilaian dengan menggunakan tes tulis (pen and paper test) masih menjadi model penilaian yang "wajib" digunakan di sekolah dasar dan lebih parahnya model tes ini digunakan untuk mengukur kemampuan siswa di semua keterampilan berbahasa: Listening, Speaking, Reading dan Writing.

Rendahnya validitas penilaian pembelajaran bahasa Inggris di Sekolah Dasar sebenarnya bukanlah murni terletak pada kemampuan guru yang mengajar saja, melainkan ada beberapa faktor lain yang turut menjadi penyebabnya. Dari hasil analisis kurikulum bahasa Inggris SD sebagai muatan lokal (mulok) yang ada di lapangan, ada beberapa titik kelemahan yang sampai saat ini masih belum bisa diatasi secara nasional, diantaranya adalah (1) kurikulum yang kurang sesuai dengan perkembangan anak usia 6-12 tahun, (2) adanya perbedaan dalam pendekatan pengembangan, tujuan, dan topiknya, tenaga lapangan yang kurang siap, serta (4) lingkungan yang belum mendukung pengembangan pembelajaran bahasa Inggris itu sendiri.

Selain itu, pengimplementasian kurikulum 2013 di sekolah dasar juga turut "memperparah" pembelajaran bahasa Inggris di sekolah dasar. Adanya wacana penghapusan mata pelajaran bahasa Inggris di sekolah dasar juga telah mempengaruhi proses pembelajaran itu sendiri. Tidak adanya ketentuan atau panduan nasional pengajaran bahasa Inggris di sekolah dasar telah menyebabkan pengajaran bahasa Inggris di sekolah sangat bervariasi antara satu sekolah dengan sekolah lainnya. Tidak adanya aturan tambahan tentang standar isi dan proses pengajaran bahasa Inggris SD menyebabkan guru-guru bahasa Inggris di SD masih mempertahankan teknik dan bentuk pengajaran KTSP termasuk model penilaiannya. Walaupun KTSP telah menetapkan otonomi sekolah dalam proses dan penilaian pembelajaran namun hal ini belum dapat diaplikasikan dengan baik di sekolahsekolah. 
Oleh karena itu, dianggap sangat penting untuk memberikan pencerahan kepada para guru bahasa Inggris sekolah dasar tentang keunggulan model penilaian otentik untuk mengukur kompetensi bahasa Inggris siswa sekaligus melatih mereka untuk menyusun instrumen penilaian otentik sesuai dengan target pembelajaran di sekolah masing-masing. Kegiatan pengabdian ini menargetkan sasaran strategis guru-guru bahasa Inggris Sekolah Dasar di kabupaten Lombok Barat mengingat terbatasnya pelatihan-pelatihan serupa bagi guru-guru di kabupaten ini.

\section{Metode}

Kegiatan pelatihan pengembangan penilaian otentik pada pembelajaran bahasa Inggris sekolah dasar ini dilaksanakan menggunakan metode atau pendekatan berikut ini, yaitu :

\section{Metode Ceramah}

Metode ceramah digunakan pada tahapan awal yaitu tahapan orientasi materi dengan tujuan memberikan pembekalan materi tentang penilaian pembelajaran bahasa, penilaian autentik, dan rubrik penilaian otentik.

2. Metode Diskusi dan Kerja Kelompok untuk mengembangkan penilaian otentik

Metode ini digunakan sebagai tindak lanjut dari orientasi materi dimana guru mendapatkan kesempatan untuk menentukan bentuk penilaian otentik yang sesuai dengan kompetensi dasar yang ada serta menyusun rubtik penilaiannya.

\section{Hasil dan Pembahasan}

Pelatihan ini dilaksanakan dalam satu hari dengan melibatkan tiga puluh orang perwakilan guru bahasa Inggris dari beberapa sekolah dasar di Kabupaten Lombok Barat. Dari ketiga puluh orang peserta ini tidak seluruhnya merupkan guru Bahasa Inggris. Ada beberapa orang guru kelas dan guru olahraga yang diutus sebagai perwakilan sekolah karena sekolah dasar tersebut sudah tidak mengajarkan bahasa Inggris lagi. Walaupun dihadiri oleh beberapa guru yang tidak mengajar bahasa Inggris, pelaksanaan kegiatan pengabdian ini tidak mengalami kesulitan karena tim pengabdian telah mengantisipasi hal tersebut dengan menyampaikan materi dalam bahasa Indonesia serta menyampaikan kemungkinan bentukbentuk penilaian otentik pada mata pelajaran yang lain, seperti pada mata pelajaran Bahasa Indonesia, Ilmu Pengetahuan Sosial, dan Pendidikan Jasmani dan Olaharaga Kesehatan. Hal ini sangat mungkin untuk dilakukan mengingat sifat dari penilaian otentik yang universal yang dapat disesuaikan dengan kebutuhan subyek dan obyek penilaian yang berbeda. Selain itu, keragaman latar belakang para peserta memungkinkan para peserta untuk bisa saling bertukar pengetahuan dan pengalaman melaksanakan penilaian pembelajaran serta saling memberikan input tentang materi yang disampaikan.

Kegiatan pelatihan ini dibagi menjadi tiga tahap, yaitu :

1. Orientasi Materi

Pada tahapan ini, peserta mendengarkan pemaparan tim pengabdian tentang penilaian pembelajaran secara umum yang kemudian dilanjutkan ke penilaian otentik pada khususnya termasuk teknik dan bentuk-bentuk instrument penilaian otentik, instrumen pendukung dan tahapan penyusunan rencana penilaian. Pada tahapan ini juga para guru diberikan contoh-contoh rencana prosedur penilaian dan instrumen tambahan seperti rubrikrubrik penilaian pembelajaran pada keterampilan bahasa Inggris seperti listening, speaking, reading dan writing.

2. Metode Diskusi dan Kerja Kelompok untuk mengembangkan penilaian otentik Pada tahapan ini, para guru dikelompokkan menjadi 5 (lima) kelompok dan diberikan latihan menyusun rencana penilaian 
pembelajaran melalui tiga tahapan, yaitu

a. Identifikasi kompetensi dasar dan menyusun indikator serta tujuan pembelajaran dari kompetensi dasar tersebut.

b. Menentukan bentuk penilaian otentik yang dapat digunakan untuk mengevaluasi kompetensi siswa pada setiap indicator

c. Menyusun prosedur penilaian dengan mencantumkan indikator/tujuan pembelajaran, waktu penilaian, teknik penilaian, instruksi ke siswa, dan hasil yang diharapkan.

d. Menyusun instumen tambahan penilaian sesuai dengan bentuk penilaian yang digunakan seperti rubrik penilaian untuk menilai kompetensi siswa "selfintroduction", menulis "teks deskripsi benda/orang".

3. Presentasi dan diskusi rencana penilaian.

Pada tahapan ini masing-masing kelompok mempresentasikan rencana penilaian mereka yang terdiri dari :

a. Kompetensi Dasar/Indikator/Tujuan Pembelajaran

b. Waktu / Durasi Penilaian

c. Bentuk Penilaian

d. Instruksi Kepada Siswa

e. Pedoman Penskoran

Selanjutnya, masing-masing komponen prosedur penilaian ini dikomentari dan diberikan umpan balik (feedback) oleh tim pengabdian dan peserta dari kelompok lain.

Dari hasil presentasi kelompok ada beberapa catatan penting yang mendapat perhatian khusus dari tim, yaitu:

1. Ketidaksesuaian antara kompetensi dasar yang harus diukur dengan jabaran indikator
2. Kurang bervariasinya bentuk-bentuk penilaian otentik yang digunakan. Untuk kompetensi dasar "memperkenalkan jati diri" misalnya, semua kelompok bentuk penilaian presentasi individu dimana siswa secara bergiliran memperkenalkan diri di depan kelas. Hal ini dianggap kurang kontekstual karena tidak adanya konteks yang aktual dari perkenalan diri tersebut. Dalam hal ini, siswa tidak akan mampu melihat fungsi sosial dari perkenalan diri dan tidak akan mampu menentukan informasi-informasi yang harus dan tidak harus dicantumkan dalam teks perkenalan diri mereka.

3. Kriteria atau deksripsi khusus dari kompetensi yang diukur tidak secara detail dan utuh mengukur keterampilan siswa.

4. Penentuan bobot penilaian yang selalu sama untuk setiap kriteria atau aspek penilaian.

Permasalahan-permasalahan tersebut diatas kemudian dicoba untuk dipecahkan dengan mendiskusikan dan menyusun bersama rencana penilaian terhadap satu kompetensi dasar pada keterampilan berbicara (speaking). Para peserta diajak untuk sama-sama menentukan aspek-aspek atau komponenkomponen penilaian dari keterampilan berbicara seperti content (isi), fluency (kelancaran), vocabulary (kosakata), grammar (tata bahasa), dan gestures (gerak tubuh). Langkah berikutnya adalah menentukan deskripsi dari komponen-komponen tersebut berdasarkan tingkat capaian yang berbeda dengan menggunakan angka $(4,3,2,1)$ atau kualifikasi (sangat baik, baik, cukup, kurang). Masing-masing tingkat capaian tersebut harus diberikan acuan penentuan capaian misalnya untuk komponen content (isi), siswa dikategorikan pada capaian tertinggi apabila isi pembicaraan sudah mencakup keseluruhan informasi yang diminta dan semua informasi yang dipaparkan dalam pembicaraannya relevan, dan seterusnya. 
Hasil kegiatan Pengabdian Kepada Masyarakat dengan tema Pengembangan Penilaian Otentik Pada Pembelajaran Bahasa Inggris Sekolah Dasar ini dapat diuraikan sebagai berikut :

\subsection{Penilaian Pembelajaran Bahasa dan Penilaian Otentik}

Setelah memperoleh orientasi materi tentang penilaian autentik pada pembelajaran bahasa Inggris di Sekolah Dasar, para guru diberikan beberapa soal tentang materi untuk didiskusikan dengan peserta lain. Dari hasil diskusi ditemukan bahwa teori-teori tentang penilaian autentik yang telah dipaparkan memang telah dipahami oleh para peserta namun ada beberapa permasalahan yang disampaikan oleh para peserta terkait pelaksanaannya di lapangan. Sebagai contoh, penilaian autentik pada pembelajaran speaking. Secara ideal, setiap siswa mendapatkan kesempatan yang sama untuk menunjukan kompetensi berbicara mereka namun alokasi waktu yang tersedia untuk pelaksanaan penilaian tersebut tidak memadai sehingga para guru sering menyiasatinya dengan mengelompokkan siswa. Siswa dalam kelompok kemudian diberikan tugas untuk melaksanakan role play atau mempraktekkan dialog. Kegiatan ini memang cukup efektif dilakukan untuk menyiasati keterbatasan waktu namun performa siswa kurang maksimal karena mereka harus berbagi peran dengan siswa yang lain. Selain itu, bentuk penilaian seperti ini juga cenderung kurang memenuhi unsur otentik (menurut pemahaman peserta) karena siswa akan mengahapalkan isi dialog dalam role play tersebut dan bahasa yang digunakan oleh siswa juga sudah disiapkan oleh guru atau sudah tersedia di buku atau LKS. Sedangkan untuk meminta siswa menyusun dialog atau role play sendiri membutuhkan waktu yang cukup lama karena kemampuan siswa yang masih rendah dan beragam.
Merespon beberapa permasalahan diatas, tim pengabdian ini memberikan beberapa alternatif teknik penilaian otentik yang bisa disesuaikan dengan kompetensi dasar yang harus diukur dan kemampuan siswa. Salah satu alternati yang bisa dilakukan dengan mengkombinasikan controlled practice, guided practice dan free activities. Dalam controlled practice semua bahan speaking disiapkan oleh guru dan peran siswa hanya mengikuti dan melaksanakannya saja, sedangkan dalam guided practice guru menyiapkan petunjukpetunjuk kegiatan sedangkan isinya dikembangkan sendiri oleh siswa sesuai dengan kemampuan mereka. Dalam guided practice, guru tidak lagi akan menilai accuracy siswa namun lebih kepada isi (content) sehingga kesalahan-kesalahan bentuk bahasa atau tata bahasa yang mungkin dilakukan oleh siswa tidak menjadi bahan penilaian. Selain kedua bentuk kegiatan penilaian ini, guru juga memberikan latihan bebas (free activities) dimana siswa diberikan kesempatan untuk menyiapkan unjuk kerja mereka secara penuh tanpa campur tangan guru lagi. Dengan memberikan ketiga bentuk kegiatan yang berbeda ini diharapkan hasil-hasil penilaian dapat digabungkan sehingga kesimpulan dari tingkat pencapaian kompetensi siswa dapat diberikan secara lebih valid dan terukur.

\subsection{Pemahaman tentang instrumen- instumen penilaian otentik}

Instumen penilaian otentik tentunya disesuaikan dengan bentuk penilaian yang digunakan. Apabila bentuk penilaiannya adalah observation dimana siswa diminta untuk melakukan observasi tentang suatu obyek maka guru harus menyiapkan lembar observasi (observation sheet) untuk digunakan siswa. Selain observasi, teknik kuesioner juga dapat digunakan untuk memberikan kesempatan kepada siswa mempraktekkan bahasa Inggris yang telah mereka pelajari. Kegiatan kuesioner ini biasanya biss dilakukan dengan cara 
melakukan class survey tentang hal-hal tertentu seperti hobi dan kesukaan seperti makanan, minuman, dan buah-buahan. Untuk teknik kuesioner ini guru perlu menyiapkan kuesioner-kuesioner untuk digunakan siswa yang biasanya berisi deskripsi dan kolom nama siswa, dan seterusnya.

Namun, salah satu instrumen penilaian otentik yang umumnya dibutuhkan oleh guru adalah rubrik penilaian. Dalam kegiatan pelatihan ini para guru peserta pelatihan diberikan beberapa contoh rubrik penilaian untuk mengukur keterampilan bahasa Inggris seperti Speaking dan Writing. Dalam pemaparan ini, peserta diberikan penjelasan tentang dua jenis rubric penilaian yaitu holistical rubric dan analytical rubric serta kelebihan dan kekurangan masing-masing jenis rubrik. Melalui contoh, guru diberikan kesempatan untuk mengomentari kedua jenis rubrik tersebut dan menentukan rubrik yang mana yang lebih sesuai digunakan sesuai dengan kebutuhan dan kondisi kelas masingmasing. Dari hasil diskusi, ditemukan bahwa para guru akan lebih memilih menyusun rubrik penilaian analytic karena jenis rubrik memberikan lebih banyak ruang untuk mendeskripsikan kompetensi siswa dalam beberapa aspek yang berbeda (yang sesuai). Selain itu rubrik analytic juga akan sangat membantu para guru ketika menyusun laporan prestasi (raport) siswa yang berbentuk raport narasi setiap semesternya. Dengan menggunakan rubrik analytic para guru dapat memberikan evaluasi dan menyiapkan penjelasan kepada para stake holders (wali kelas, kepala sekolah, orang tua, bahkan siswa itu sendiri) tentang aspek-aspek berbicara (speaking) yang masih perlu diperbaiki oleh siswa, dan hasil penilaian dari rubrik analytic kemudian bisa menjadi dasar untuk menentukan tindak lanjut terhadap penilaian tersebut.

\subsubsection{Deskriptor atau Indikator Kompetensi di Rubrik Penilaian}

Setiap rubrik menggunakan kriteria performa atau deskripsi kompetensi sebagai acuan penentuan tingkat kompetensi yang dicapai siswa. Deskripsi atau kriteria adalah kondisi dari performa yang harus dicapai karena setiap deskripsi kompetensi menyatakan bagaimana kompetensi tersebut dicapai. Bagi para peserta pelatihan, menyusun deskripsi kompetensi bukanlah hal yang mudah karena mereka harus mampu menganalisa kompetensi dasar terlebih dahulu. Misalnya untuk menyatakan bahwa siswa telah "mendengar dengan efektif rangsangan dari pasangan bicaranya" bisa kemudian diturunkan menjadi dua deskripsi yaitu "memahami pesan yang disampaikan pasangan bicaranya" dan "membuat bahasanya mudah didengar oleh lawan bicara".

Di dalam menyusun deskripsi yang mengindentifikasikan indikator khusus bahwa siswa telah memenuhi kriteria atau tidak, para guru mengalami kesulitan dalam menentukan kata-kata kunci indikator pencapaian kompetensi. Namun dengan bimbingan selama pendampingan oleh tim pengabdian, para guru dapat menyusun deskripsi dengan cukup baik walaupun setelah melalui beberapa kali revisi. Masalah yang paling dominan timbul adalah banyak deskriptor rubrik yang disusun tidak dapat mengukur kompetensi yang diharapkan sehingga kurang valid untuk digunakan. Selain itu, dalam tahapan presentasi dan diskusi, para guru semakin memahami kekurangan rubrik mereka masing-masing. Para guru memang harus lebih hati-hati dalam menyusun indikator atau deskriptor pencapaian karena ada beberapa rubrik juga yang mencantumkan kompetensi yang sulit atau tidak sesuai dengan tingkat kompetensi siswa. 


\subsubsection{Skala atau Rentang Nilai dalam Rubrik}

Pada umumnya, sebuah rubik menggunakan skala nilai berupa angka untuk mewakili kualitas performa atau tingkat pencapaian kompetensi oleh siswa. Angka tinggi untuk performa yang tinggi dan sebaliknya angka rendah untuk performa dibawahnya seperti 5, 4, 3, 2, 1 atau 4, 3, 2, 1, 0 . Selain menggunakan angka rubrik juga bisa menggunakan jabaran kata standar sebagai pedoman penskoran, misalnya above the standard, on the standard, dan below the standard. Apapun skala nilai yang digunakan, angka atau standar yang ditentukan tetap harus didukung dengan deskriptor yang tepat sehingga angka yang diberikan sebagai nilai dapat dijelaskan dan lebih bisa dipertanggungjawabkan validitasnya. Dalam menentukan skala atau rentang nilai pada rubrik, para guru tidak mengalami kesulitan sama sekali. Kesulitan yang paling besar dihadapi adalah pada penyusunan deskriptor atau indikator performa seperti yang dijabarkan sebelumnya.

\section{Saran}

Melaksanakan evaluasi pembelajaran atau penilaian merupakan bagian yang tidak dapat dipisahkan dari proses pembelajaran. Sebagai guru yang profesional, pelaksanaan penilaian haruslah dapat menjadi momentum sebagai evaluasi yang sesungguhnya terhadap proses pembelajaran itu sendiri yang juga mencakup evaluasi terhadap perencanaan pembelajaran. Mengembangkan dan menggunakan lebih banyak bentuk penilaian otentik yang valid dapat menjadi salah satu upaya guru untuk mengukur kompetensi siswa sehingga hasil penilaian yang diperoleh dapat dipertanggungjawabkan. Berdasarkan proses dan hasil pelatihan pada program Pengabdian Kepada Masyarakat ini, ada beberapa rekomendasi atau saran yang dapat kami berikan, diantaranya adalah :

1. Materi yang telah diperoleh dari kegiatan pengabdian ini diharapkan agar dapat benar-benar dimanfaatkan oleh para peserta sebagai bahan untuk mengembangkan bentuk-bentuk penilaian otentik lainnya pada kompetensi dasar yang berbeda.

2. Para peserta Pengabdian Kepada Masyarakat ini dapat menularkan ilmu dan pengalaman yang diperoleh pada kegiatan pengabdian ini kepada guruguru lain yang belum mendapatkan kesempatan yang sama.

3. Perbaikan atau pengembangan bentuk penilaian otentik yang disusun perlu terus dilakukan secara berkala sesuai dengan perkembangan dan kebutuhan kelas masing-masing

4. Pimpinan sekolah diharapkan dapat terus memotivasi guru dengan berbagai bentuk agar semangat dan konsistensi guru dalam menjamin kualitas pembelajaran dan penilaian tetap dapat dipertahankan dan ditingkatkan pada masa yang akan datang.

\section{Ucapan Terima Kasih}

Penulis mengucapkan terima kasih kepada Lembaga Penelitian dan Pengabdian Universitas Mataram yang telah mendanai kegiatan Pengabdian pada Masyrakat ini.

\section{Daftar Pustaka}

Brown, H.D. (2007). Prinsip Pembelajaran dan Pengajaran Bahasa. Pearson Education, Inc.

Essberger, Josef, (2001), "Speaking Versus Writing", taken from http://www.englishclub.com/eslarticles/200108.htm. Retrieved on 17th February, 2013. 
Hughes, A. (2003). Testing for Language Teachers. Cambridge University Press. UK, England

Luoma, S. (2004). Assessing Speaking. Cambridge University Press. UK, England.

Moss, C.M. \& Brookhart, S.M. (2009). Advancing Formative Assessment in Every Classroom. ASCD, Alexandria, Virginia.

Musaddat, S., Rohana, S., \& Mar'i. (2011). Pendidikan Bahasa dan Sastra Indonesia Kelas Rendah. Cerdas, Mataram.

Suyanto, K.K.E. (2007). English For Young Learners. Bumi Aksara. Jakarta 